\title{
9. The Dynamics of Professional Values in Officership: A study of 300 Years of Officer Performance Evaluation Systems
}

Vilhelm Stefan Holsting

\section{Introduction: The Dynamics of Professional Military Values}

Western military institutions have seen a degree of transformation in recent decades, prompting much discussion on values considered core or arbitrary to the military profession (Williams, 2008, p. 200). In this chapter, I argue that we must develop a greater understanding of the origins and development of military values in order to more accurately understand their continued significance for military professionalism and civil-military relations; in this way, we will arrive at a better understanding of the nature and effects of such transformations.

While military sociology has sought to understand the nature, origins and development of professional values, classical sociology has offered little to our

1 Founded on data collected for the author's Ph.D. project on senior officership in the political-professional relation (Holsting, 2017), this chapter expands on the general conclusion about value sediments. 
understanding of the historical relation between military development and social change (Burk, 1993, p. 167). In military sociology, opinion has been divided on whether military values are unique and universal, as argued by Samuel Huntington (1985), or unique but influenced by society, as argued by Morris Janowitz (1971) and Bernard Boëne (1990, p. 59), or under constant pressure, sometimes even replaced by external values on account of societal change, as argued by Charles Moskos (1977) and by John Williams (2008, p. 215), who concludes: "When societal values change, so also will those of [the] military." In Denmark, the latter position was concretely reflected recently when the Danish Chief of Defence, addressing the entire corps of officers after several years of transformation, stressed: "The values of the military are the values of the Danish society translated into a military framework" (Chief of Defence 2020, p. 1).

As Boëne (1990, p. 11) states, however, influential practitioners frequently present military values as universal and unique; for Sarkesian (1981, p. 11), these values include "honesty, integrity, loyalty, honor, and gentlemanly conduct." Although such values may be considered unique by many, they are typically described so weakly and in such superficial terms that they could easily represent values of other social groups - or simply mirror ephemeral or obsolete societal values. Even Samuel Huntington (1985) and Morris Janowitz (1971) offer us empirically imprecise historical understandings of military values; Libel (2020, p. 16) was not alone in his assertion that both arrived at "conclusions considering the nature of military profession without empirical exploration." Detached from their concrete historical and professional qualities, military value statements seem to be drained of their influence on today's military reforms; current public governance seems to prefer specific requirements on behalf of "diffuse professional norms," as stressed by Leicht, Walter, Sainsaulieu and Davies (2009, p. 585). The issue of military values was, for example, largely neglected in the political agreement leading to radical reductions and a restructuring of military training, organisation and high command in the Danish Armed Forces in 2012 (Holsting, 2017, p. 318).

More empirical clarity on the historical emergence of values at the civil-military boundary, and the ways in which those values become core components of the professional repertoire, is needed. Military sociology needs to provide a thorough empirical understanding of how military values emerge in order to gain a more accurate perspective on contemporary disruptions to these values. Through an examination of a unique archive of military performance evaluation systems used by the Danish military in the course of 300 years, this chapter sets out to analyse how values of officership have developed over the centuries and what this development tells us about the dynamic relationship between military values and societal change. 


\section{A Sociological Perception of the Emergence of the Military Profession and its Values}

It is generally understood in the field of sociology that the army officer corps began to develop professional characteristics in the early 18th century (Huntington 1985, p. 19). Norbert Elias has argued that, during this time, certain technological and societal developments saw bodies of "gentleman" officers with fighting skills and sailors with navigational and sailing skills merge to become a corps of naval officers (Elias, 2007).

The historical contemporaneity of army and navy professionalisation allows us to speak of a general military professionalisation, even if the two services developed along different lines. Based on historical studies of these services, Gerke Teitler (1977, p. 112) proposed: "The characteristics of a professional military corps amount firstly to possession of technical competence, secondly, military traditions, a code of honor and the sense of sharing a common fate, and lastly, the ethos of service to the State." Whereas technical competences and the code of honour are deeply rooted in the military operational environment, the ethos of service to the state is undoubtedly a core integrating aspect of the military as a societal entity. Notwithstanding Teitler's rigorous examination of professionalisation, we still arrive at a perception of military values as unique and universal rather than as responsive to dynamic civil-military relations.

Even Janowitz (1971, p. 23) argued: "Most fundamentally, the professional soldier is conservative, since his social origin is grounded in the history of the post-feudal nobility in Europe and its social equivalents in United States. His prototype is the Prussian officer corps." It is unclear, however, how this "post-feudal nobility" officership became, and continues to be, a core part of professional self-understanding across different service branches and societal configurations.

Conversely, Charles Moskos's 1977 examination of the military, leading to the widely used Institutional/Occupational (I/O) model, implies a significant emergent societal relation. For Moskos, traditional institutional military values like sacrifice, esprit de corps and passion related to a military calling were replaced by occupational civilian market values like individualisation, cost-benefit and self-interest. John Williams (2008, p. 200) later expanded on this notion of military (de)professionalisation, relating the value dynamics to the effects of post-modernism. For Williams, "effects include serious challenges to traditional military culture, such as cultural relativism and the imposing of non-military social, ethical, and political criteria of evaluation on their militaries." If the societal effect is so pervasive today, one might ask, how is it that the officer's values were previously so unique and universal? 
Military sociology, this is to say, does not provide us with any convincing, detailed, historical understanding of the relationship between social development and the diachronic emergence of military values. Most arguments along the lines of those made by Moskos and Williams leave an impression of continuing deprofessionalisation, in the sense that universal military values sense are arbitrarily forced on the military, causing cultural relativism and thereby loss of a military calling and a genuine fighting spirit. The authors do not demonstrate, for example, how the military profession thoroughly incorporates new values through a pragmatic and logical process of accommodation to societal change through, say, alterations of performance evaluation systems. It is easily overlooked that societal changes can become catalysts for new military values, not only through the military's reluctant adaption of civil values but also through a more active and engaged process reshaping professional functionality and legitimacy for a new era.

\section{A Unique Opportunity to Study the Deep Historical Development of Military Values Empirically}

While no previous project has systematically studied the transformation of military performance evaluation systems, there have been studies of the historical development of performance evaluations or appraisals as an organisational practice (Scott, Clothier \& Spriegel, 1941; George, 1972; Weise \& Buckley, 1998). According to Weise and Buckley, performance evaluations, as means to the systematic improvement of efficiency, were an artefact of industrialisation in the 18th century; it should be noted that the systematic performance evaluations of American officers conducted during the First World War itself prompted a more extensive business-oriented performance evaluation practice.

Nevertheless, a general breakthrough of performance evaluations in the labour market, including that of Denmark, did not arrive until after the Second World War (Carlsson, 1948). During the war, the United States and Great Britain re-established the field of military psychology, then dormant after its inception in the First World War. The Danish Armed Forces drew on this in the forming of scientifically based scales and evaluation criteria (Psykologikommissionen, 1949; Weise \& Buckley, 1998, p. 233-235). Between the 1950s and 1970s, Peter Drucker's development of management by objectives and Douglas McGregor's work motivation thus served to widely inspire performance evaluation practices (Murphy \& Cleveland, 1995). Some slightly earlier forerunners to those emerging management concepts appear in the Danish Navy and Air Force evaluation systems of 
1949 to 1950 (Marineministeriet, 1950; FOARK 3; FOARK 6) and continue in the first joint system, FORPUBS, from 1976 (Forsvarsministeriet, 1976). Systematic performance evaluation, then, has been widely used in a military context for some time, its methods mutually inspirational for military and civil society.

Those performance evaluation systems are relevant today mainly due to their historical significance, notably for how they formed the military as a part of society. Danish military performance evaluation practice is unique - not because other professions or military systems do not conduct performance evaluations, but because, owing to Danish archival practice, documentation has been preserved for more than 300 years (Holsting 2017, p. 142). By offering a very homogenous, diachronic data-set, these documents provide a unique opportunity for the empirical understanding of changes in the prioritisation of military values over a long term.

\section{Theorising a Plurality of Values}

In order to examine changing values of officership, I draw on Luc Boltanski and Laurent Thévenot's work of 2006 on orders of worth, notably pragmatic conceptualisations of justification and the plurality of incommensurable values. The analytical approach to the empirical exploration of values has been widely discussed since Parsons (1983, pp. 27-28) made the argument that values, formed by normative agreements, were "the very heart of the human enterprise... what made social order possible and what made the order potentially resistant to evolution." Boltanski and Thévenot then described how moral judgements of people and things operate through a repertoire of moral modes or values. Common values must reference an idea of the common good, which has historically proven its worth in practice by becoming institutionalised and a viable part of social life. Moreover, such common values cannot be reduced to one higher universal value. By applying a pluralistic value approach, it is possible to observe the heterogeneous value dynamics in the military profession.

Here, this value approach is used as an analytical framework, empirically sensitive across time and capable of observing diverse values both at a societal and a professional level. Boltanski and Thévenot's (2006) framework consists of a number of historical values, or modes of worth. Originally, they used those modes to understand patterns in the way individuals justify their actions to others in order to command respect, first identifying six competing values with diverging quality

2 The Danish Armed Forces archives at the Danish National Archives; the number refers to a specific sub-unit in this archive (see Appendix 1.) 
criteria (Table 1): inspiration, opinion, domesticity, market, industry and civic. Later, Boltanski and Chiapello (2007) added a seventh, the project value, in their influential work The New Spirit of Capitalism; oriented to the future, the project value contrasts diametrically with domesticity, a value rooted in the past. Boltanski and Thévenot derived the project value from studies of the diachronic transformations of social coordination under capitalism between the 1960s and the 1990s. The authors' analytical strategy is similar to that employed here.

In the 2012 work Love and Justice as Competences, Boltanski further outlined other modes of action also representing distinct values. These are the modes of $v i$ olence, love and fairness. I have previously translated these values into military terms in order to use them analytically in a military context (Holsting, 2017, p. 72-79; 115-140). With reference to Carl von Clausewitz's (1981) description of warrior spirit, the mode of violence in the legitimate sense of power of action has been translated into the value of execution; the mode of love was translated into the value of scarification; representing the band of brothers, into the value of brotherly love shared between members of a team enduring great risk in the course of action; the mode of fairness was translated into the value of subordination, representing the naturalness of obedience and discipline in military behaviour.

In my analysis, the ten values are used in combination with a conceptual-historical approach inspired by Reinhart Koselleck (2002). Here, the values, which officers connect to through the quality criteria inherent in the performance evaluations, can be seen as core signifiers capable of transforming the value framework of officership. The changing criteria in the systems are, on the one hand, imprints of the historical events that move the language of the actors; on the other hand, the criteria themselves act as catalysts for historical development, in the sense that language also influences practice (Koselleck, 2002). Consequently, the observation of criteria related to values in officership as they appear in performance evaluation systems is categorised in accordance with this conceptual framework of the 10 values in accordance with Table 1. By applying this framework to the changing military evaluation systems, it is possible to map and to track how values emerge and change historically in the military. 


\begin{tabular}{|l|l|l|l|l|}
\hline Values & \multirow{2}{*}{ Principles } & \multicolumn{3}{|l|}{ Quality Criteria/Behaviour (examples) } \\
\hline Inspiration & Geniality & Experimenting & Challenging & Innovative \\
\hline Opinion & Fame & Convincing & Reputable & Respected \\
\hline Domestic & Honourability & Authoritative & Loyal & Dutiful \\
\hline Market & Competition & Opportunistic & Competitive & Efficient \\
\hline Industrial & Effectiveness & Productive & Structured & Reliable \\
\hline Civic & Community & Unifying & Egalitarian & Fair \\
\hline Project & Agility & Flexible & Connective & Holistic \\
\hline Execution & Power & Strong-willed & Resilient & Solution-oriented \\
\hline Sacrifice & Devotion & Caring & Passionate & Unselfish \\
\hline Subordination & Naturalness & Obedient & Disciplined & Tolerant \\
\hline
\end{tabular}

Table 1. Framework of common values related to officer performance evaluation reports.

\section{Data and Methods}

Approximately 3000 individual evaluations from Army, Navy and Air Force have been analysed and interpreted with the support of contemporary military administrative regulations, textbooks and professional journals discussing officership, professional values and evaluation practices (see Holsting, 2017, pp. 84-87; 142-171).

I have identified changes in evaluation systems by comparing archives containing individual performance evaluations and archives containing military regulations. The historical mapping of performance evaluation systems is challenging; until 1880, administrative practice was markedly less consistent to that of the following period. Further, the Navy and the Army followed different tracks until 1976, even though their practices inspire each other on occasion.

Since performance evaluation systems were initially ungoverned by standardised regulations, the period between their inception in 1690 and the 1880s was examined through a review of the first box of archived evaluations for people whose surnames began with the letter "A," where evaluation categories, evaluating comments and details for the actual evaluations were meticulously recorded. This proved a useful means of clarifying the specific historical use of evaluation systems, notwithstanding certain uncertainties: the exact year when one system replaced another is not always clear, for example; being un-standardised by regulations and often hand-copied, variations between the early systems were not fully recorded; and it is difficult to say how frequently evaluations were performed in, say, the 18th century. Consistency improves in all of these conditions from the early 1800s, however, and from the middle of the 19th century, the systems were regulated with pre-printed forms, regulations and guidelines. 


\begin{tabular}{|c|c|c|c|}
\hline \multicolumn{2}{|r|}{ Army } & Navy & Air force \\
\hline \multirow{2}{*}{$\begin{array}{l}\text { ? } \\
\text { ผุ๊ } \\
\rightarrow\end{array}$} & $\begin{array}{l}\mathbf{1 7 3 0 - 1 7 6 4} \\
\text { First observed } \\
\text { conduct protocols } \\
\text { (only occasional evaluations). }\end{array}$ & $\begin{array}{l}\mathbf{1 7 3 0 - 1 7 6 4} \\
\text { First observed } \\
\text { conduct protocols } \\
\text { (only occasional evaluations). }\end{array}$ & \\
\hline & $\begin{array}{l}\text { 1764-1867 } \\
\text { First pre-printed conduct } \\
\text { protocols with fixed evaluation } \\
\text { categories and evaluation scale } \\
\text { (only occasional evaluations } \\
\text { until ca. 1800). }\end{array}$ & $\begin{array}{l}1756-1780 \\
\text { Conduct protocols with } \\
\text { continuous evaluations on } \\
\text { officers. }\end{array}$ & \\
\hline \multirow{4}{*}{$\begin{array}{l}\text { ? } \\
\text { ஸू } \\
\stackrel{N}{N}\end{array}$} & $\begin{array}{l}\mathbf{1 8 6 7 - 1 8 8 1} \\
\text { Promotion protocols, purely } \\
\text { free text (identical for the } \\
\text { entire Army). }\end{array}$ & $\begin{array}{l}\mathbf{1 7 8 0 - 1 8 6 9} \\
\text { First pre-printed conduct pro- } \\
\text { tocols with fixed evaluation } \\
\text { categories and evaluation scale } \\
\text { (identical for the entire Navy). }\end{array}$ & \\
\hline & \multirow{3}{*}{$\begin{array}{l}\text { 1881-1976 } \\
\text { First pre-printed individual } \\
\text { evaluation form. } \\
\text { Identical for the entire Army. } \\
\text { Primarily free text with few } \\
\text { fixed evaluation categories. }\end{array}$} & $\begin{array}{l}1869-1880 \\
\text { Promotion protocols with fixed } \\
\text { evaluation categories and } \\
\text { evaluation scale. }\end{array}$ & \\
\hline & & $\begin{array}{l}\text { 1880-1935 } \\
\text { First pre-printed individual } \\
\text { evaluation form. Still with } \\
\text { fixed evaluation categories } \\
\text { and scale. }\end{array}$ & \\
\hline & & $\begin{array}{l}\mathbf{1 9 3 5 - 4 8} \\
\text { Increased number of } \\
\text { evaluation categories. }\end{array}$ & \\
\hline \multirow{2}{*}{ 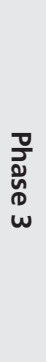 } & & $\begin{array}{l}\text { 1948-1976 } \\
\text { First scientifically based } \\
\text { system (psychology) and } \\
\text { new evaluation categories. }\end{array}$ & $\begin{array}{l}\text { 1950-1976 } \\
\text { First Air Force system } \\
\text { combining parts from } \\
\text { contemporary Army } \\
\text { and Navy systems. }\end{array}$ \\
\hline & \multicolumn{3}{|c|}{$\begin{array}{l}\text { 1976-2007 (FORPUBS) } \\
\text { First joint evaluation system. Second scientifically based system (psychology/sociology) } \\
\text { including fixed categories like Navy/Air force and free text in the Army. Including feed- } \\
\text { back and relational development dialogue }\end{array}$} \\
\hline 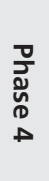 & \multicolumn{3}{|c|}{$\begin{array}{l}\text { 2007- (FOKUS) } \\
\text { Second joint evaluation system. First system developed in dialogue with users, still with } \\
\text { fixed evaluation categories and free text. }\end{array}$} \\
\hline
\end{tabular}

Table 2. Different performance evaluation systems over time in all services. 
Table 2 illustrates the analysed performance evaluation systems in specific timeframes divided by services. The general phases illustrated in the first column, reflecting Figure 1, will be substantiated in the following section.

Until the military reforms following the Second Schleswig War in 1881, the Army and Navy systems were described as "conduct protocols"; after this, they were described as "promotion protocols" or "promotion evaluations" as they became more closely related to systematic meritocratic promotion practices (Krigsministeriet, 1881; Marineministeriet, 1881). From the inauguration of the first joint system (FORPUBS) in 1976, the systems are described as "combined evaluation and development forms." In the current system (FOKUS), they are described as a "competence development" system. The latest two systems include development dialogues; all preceding systems were pure rating tools kept secret from the evaluated officers. The Navy system from 1948 was the first system based on a scientific approach with psychological evaluation categories; FOKUS became the first system developed in dialogue with the users. Those differences are related to societal changes and represent the phases unfolded below.

\section{Categorisation of the Epochal Emergence of Values}

The complete examination of performance evaluation systems from the earliest attempt in 1690 to the most recent version of 2006 reveals four general phases concerning the character of values as outlined in Table 1 . The four very different types of ideal officer revealed here - the sovereign patriarch, the patriarchal administrator, the professional bureaucrat and the calculative change agent (Figure 1) - relate to and promote specific values indicated in Table 1 and, together, demonstrate the link between professional and societal development.

\begin{tabular}{|l|l|l|l|}
\hline Soverign & Patriarchal & Professional & Calculative \\
Patriarch & Administrator & Bureaucrat & Change Agent \\
Until the 2 $2^{\text {nd }}$ Schleswig War & Until World War II & During The Cold War & During 'Globalization' \\
Primarily Domestic & Primarily Domestic & Primarily Industrial & Primarily Industrial \\
and Subordination & and Industrial & and Civic Values & and Project Values \\
Values & Values & Supplemented by & Supplemented by \\
Supplemented by & Supplemented by & Execution and & Execution and \\
Execution and & Execution and & Sacrifice & Sacrifice \\
Sacrifice & Sacrifice & & \\
\hline
\end{tabular}

Figure 1. Breakdown and development of professional values in officership through four historical phases. 
Even though the above is derived from classified performance evaluations relating only to internal discipline and to the career of specific officers, the values represented in the table do not only relate to internal professional concerns; they represent the different ways in which the profession has managed the societal function it is assigned. In the following, I will analyse how the four periods of qualitatively different ideals of officership correspond to societal change.

\section{Phase 1: to the Second Schleswig War Ideal officer type: the sovereign patriarch in the autocratic society}

In Phase 1, officership was mainly based on a traditional domestic value combined with strict subordination values supplemented by execution and sacrifice. Here, the officer, most often a member of the nobility, represented the ideal of the sovereign patriarch: formidable, often strict and punishing, yet a caring father figure generally possessed of a blind loyalty to king and country, bound by a divine oath and societal privileges. This ideal conformed to the contemporary model of governance in Denmark: an autocratic, absolute monarchy, regulated by law between 1660 and 1849 (Olden-Jørgensen, Lyngby \& Mentz, 2010). As such, this form of ideal officer reflected the sovereign patriarch by combining the attributes of the uncontestable, strict leader with the caring pater familias.

Turning to quality criteria, principles and values, the earliest evaluation systems found in the archives of the Danish Armed Forces (FOARK) appear to be older than those identified in the earlier studies mentioned by Weise and Buckley (1998); "Niels Juell's Conduct List of the Navy's Officer Staff of 1690" (von der Recke, 1861) may represent the earliest systematic attempt to evaluate the quality of military personnel in Denmark.-

As early as the late 17th century, we find fixed evaluation criteria in the Navy such as "knowledge of the service in general," "activity in service in general," "performance during command," "seamanship," "subordination," "relation to subordinates," "inspection of order and cleanliness," "economically responsible" and "viability for higher appointments" (FOARK 22).

In the Navy, especially, pre-printed protocols were systematised and based on the same evaluation criteria from the end of the 17th century until the 1880s. In the Army, on the other hand, we see various practices, apparently inspired by the Navy lists (FOARK 23), including pre-printed checkboxes related to different aspects of officership. From the 1880s, the Army began to develop its own format emphasising the evaluators' personal evaluation comments (FOARK 13; 17). The services of both protocols initially reveal a general focus on obedience, energy (drive) and good behaviour, and thus on values related to strict subordination, execution and domesticity. 
The conduct protocol of the 1st Battalion of the Zealand Hunter Corps, 30 September, 1814 offers a typical example of a contemporary evaluation system. Here, a Regiment commander evaluates his second in command, leading the regiment in his absence: "A man of boundless honesty. In my $21 / 4$ years absence commanded and kept together the regiment with much order and honour" (FOARK $23,6)$. The officer was classified as "Good" under the evaluation category "Command with dignity and good manners" (a domestic value); "Very Good" under the evaluation category "Subordination and, as a result, Prompt Obedience in Executing Superiors' Commandments" (strict subordination); and "Good" under the evaluation category "Cool and tireless Courage, and quick-witted and decisive in the moment of danger" - values of execution and sacrifice (FOARK 1; 9; $10 ; 13 ; 14 ; 19 ; 20 ; 22 ; 23)$. Together, these qualities demonstrate the primary values of the first phase in general, and, specifically, values forming the ideal officer during the period of autocracy enduring in Denmark until the mid-18th century.

\section{Phase 2: to the Second World War Ideal officer type: the patriarchal administrator during industrialisation}

The second phase began in the contexts of the comprehensive industrialisation of the military in the 19th century and a period of national and military self-examination after the shock of Denmark's defeat to Prussia and Austria in the Second Schleswig War. A new form of officership began to appear, combining the emerging industrial value of effectiveness with the older, enduring, patriarchal domestic value, thereby recreating the profession of military officer as what might be described as a patriarchal administrator. These new values, still supplemented by execution and sacrifice, together created a new ideal type, which, while it continued to hold an elevated position, was increasingly upheld and regulated by bureaucratic and mechanical standards such as manuals and doctrines related to the technologicalisation and professionalisation of increasingly complex capabilities and battlefields.

The ideal of the patriarchal administrator, prominent throughout the First World War, endured until the Second World War, reflecting a time of increasing industrialisation in both the societal and military spheres. At the societal level, bureaucracy and Fordism dominated social and organisational transformations; at the military level, the ideal reflected a progression from manpower and horsepower to the railway engine, and from sail to engine - in short, to what has been called "thermodynamic warfare" (Bousquet, 2009, p. 921) characterised by the rise of mass armies, total warfare and nuclear weapons. Here, the ideal officer archetype should embrace and master the scientific way of warfare. 
These thermodynamic transformations involved the implementation of a system of meritocratic advancement in the officers' corps, which gradually replaced the autocratic and aristocratic military order where advancement had been contingent on class and age (Huntington, 1985, p. 31). It is essential to consider the corollaries in the criteria, principles and values defining the period's evaluation systems in this light.

New methods of performance evaluation began to alter traditional systems of advancement founded on the principles of the domestic value. According to a military proclamation ("Kundgørelse for Hæren") of 1867, the previous age-based protocols for advancement could thus be supplemented with so-called promotion lists which should be based on eligibility for promotion: "The officers are listed on promotion lists in the order in which they are considered eligible, including the specific grounds for such recommendation" (Krigsministeriet, 1867, p. 37; 1868a).

Similar substantiation requirements also began to gain ground in other aspects of contemporary staff administration. In 1881, for instance, a military criminal code was introduced; with it military legal practice began to resemble civil legal practice by limiting the right to sentence individuals without trial (Forsvarsministeriet, 2005). The will to regulate good conduct through even more specific regulations suggests that the administrative practice was shifting from more or less unwritten domestic rules towards industrial-bureaucratic principles of administration. Even though the Army and Navy introduced very different systems, they both began to assign more weight to the individual substantiation requirement. In this period, that is, class and age were superseded by a meritocratic principle of advancement as the guiding and defining values of officership gradually shifted from the domestic to the domestic-industrial (Krigsministeriet, 1868b; $1870 ; 1880 ; 1908 ; 1939)$. As a naval evaluation of the second-in-command of the ironclad Lindormen attests:

A skilled and polite officer with excellent knowledge of the service and very efficient. Throughout his conduct, he behaves very militaristically, independently and reliably. Very skilled as a sailor and pilot, excellent organiser, very good command, excellent ability to get along with subordinates. He is a gifted and highly educated man.

(FOARK 4: Promotion evaluation, 1889)

"Polite," "militaristic" and "educated" all relate to the domestic value; "efficient," "reliable" and "excellent organiser" relate to the industrial value. The quality criteria of both values seem equally important as signifiers, thereby stressing the predominant domestic-industrial value. 


\section{Phase 3 - During the Cold War \\ Ideal officer type: professional bureaucrat in a modern democracy}

In the third phase, covering the aftermath of the Second World War and the general rebuilding of the Danish Armed Forces, values in officership once again transformed in relation to societal change. The changes occurred gradually in Phase 3 alongside a military adaptation to NATO membership from 1949 and the emergence of the Danish welfare society which included the evolving rights- and efficiency-based civil labour market in the 1950s and 1960s. The former resulted in an Anglicisation of material, education, procedures and language; the latter finds its expression in the unionisation of military personnel and gradual adaption of labour market standards parallel to the I/O model proposed by Moskos (1977). These changes represented a re-professionalisation of the officer corps, this time based on a civic value and combining a pedagogy-, democracy- and cooperation-based officership with industrial values of standardisation and mass production, necessitated by the need for a huge number of enlisted personnel.

The general democratisation of the educational system was also reflected in a new approach to military leadership (Jensen, Olsen, Svensson \& Zilmer, 2004). Here, strict subordination made way for a dialogic subordination (Holsting 2017, p. 204) both in the political-professional relation and between ranks, which in turn also reflected the transformation of the public sector from the 1960s. To a high degree, authority was delegated from the central administration to the professions (Administrationsudvalget, 1966). This was also the case for the new joint chief, the Chief of Defence, who gradually became the most prominent professional expert between the 1970s and the 2000s. Here, the ideal officer was considered a professional bureaucrat (Rennison, 2011), enjoying strong positions of expertise and professional autonomy (Forsvarskommandoen, 2000). Professionally, the ideal officer became the expert, with the highest technical skill and, in consequence, the ability to teach and motivate his subordinates - an educator subject to science and law more than an omnipotent and sovereign ruler.

In practice the starting point of the general transition was a pedagogical working group, The Army Pedagogical Working Group established in 1961 to examine an increased number of disciplinary and educational problems (Heise, 1953, pp. 49-69; Sabroe \& Rieneck, 1968, p. 3; Berg, 1967, pp. 153-164). Politically, the so-called Højby Committee provided a series of reports identifying a problematic working environment and an increasing divergence between military leadership habits and emerging democratic and humanistic societal standards (Forsvarsministeriet, 1966a; 1966b; 1969a; 1969b; Petersen, 1967). As this coincided with a revision of the pedagogical principles used in Danish primary and 
lower secondary schools in the 1960s and a democratisation of teaching methods, a similar revision of pedagogy and leadership in the Danish Armed Forces was considered timely at the political level.

Driven by the joint Defence Command established in 1970, this resulted in a number of joint initiatives focused on the creation of a new industrial-civic officer ideal, attained through leadership courses and directives focusing on leadership and pedagogy (Hærkommandoen, 1969; Forsvarskommandoen, 1976; 1978). This fundamental shift in leadership ideals is evident in the following quote from the Defence Ministry: "The leader must safeguard the interests of the group if he is to be accepted by the group and thus affect the development of norms ... The leader will shatter his personal authority if he attempts to lead exclusively through orders of obedience" (Forsvarsministeriet, 1966a, pp. 17-18). From this point, then, officership was to rely on informal acceptance among the subordinates rather than fear of punishment. Traditional, strict subordination was thus replaced by pedagogy and democratic-inclusive ideals. The leader should be able to "explain, discuss, stimulate group decisions and leave decisions to the group" (Forsvarsministeriet 1966a, p.18).

The first joint performance evaluation system, FORPUBS (Forsvarsministeriet, 1976), was implemented in 1976. In general, it stood out in two ways compared with former evaluation systems. First, it was founded on the Navy and Air Force systems of 1949 and 1950 (FOARK 3 \& 6), based on insights from the fields of psychology and sociology. FORPUBS thus paved the way for knowledge-based evaluation criteria at the expense of the preceding "common sense" criteria.

Second, FORPUBS represented the new leadership ideal. It paved the way for the principles of the civic value in officership - that is, principles of influence, participation and delegation - and thereby broke with the traditional values of domestic order and subordination. New evaluation categories such as "pedagogical talent" "Presents and explains topics in a motivating and comprehensible way"), "cooperation" "CCommunicates participation in solving joint tasks, participates actively in solving those tasks and ensures mutual orientation") and "delegation" ("Delegates tasks appropriately and exercises the necessary control of completion") made their way into officership as new civic evaluation categories.

As such, FORPUBS became a core institutional part of the transition in leadership values during the third phase, in which civic values of officership emerged - even if, in practice, the "autocratic" domestic value continued to prevail until the late 1980s, representing a lengthy gap between emerging professional and democratic standards and traditional professional self-understanding. This remark from the evaluation of a lieutenant colonel in the 1980s offers a typical example of the tension between traditional authority and civic values: "In his 
eagerness to find the best solution at all times, however, he seeks more acceptance and support than he needs. Consequently, it must be estimated that a more autocratic leadership would be fully accepted, both by superiors and subordinate leaders" (FOARK 8: FORPUBS, 1981).

In other words, it is possible to trace a measure of scepticism toward democratic-civic ideals. Many officers had not yet come to appreciate the values of this new paradigm of officership.

\section{Phase 4 - the Globalised Era \\ Ideal officer type: the calculating agent of change in an era of globalisation}

The most recent period in which the values of officership have experienced change is that of the post-Cold War years, the era of global governance (Finkelstein, 1995).

Here, the archetype of the ideal officer is shaped by two simultaneous societal drivers. The first is formed by the political ambitions of global governance, which include an assertive security policy resulting in multiple "out of area" operations, primarily in the Balkans, the Middle East and Afghanistan (Pedersen, 2012). Here, the ability to conduct full-scale operations, tactical flexibility, rapid reaction and continuous adaptability became core professional elements. The second driver was the economic logic behind public modernisation - the so-called New Public Management programmes (McLaughlin \& Osborne, 2010) - which became an inherent part of all political defence agreements, principally from the 2000s. The alteration of officership values provoked by these forces emerged as the combination of industrial and project values; the associated ideal officer type is that of the calculating agent of change (Holsting, 2017, p. 192) who constantly strives to rationalise, optimise and innovate by breaking with previous military practices and traditions to get the most, militarily speaking, out of the least possible resources. Here, the enduring domestic value is generally repressed. The officer who safeguards the traditional order increasingly comes to stand in opposition to the continuous demands for change. The contradictions between project and domestic values also constitute a tension amongst the professional actors: it is difficult to simultaneously maintain both domestic values and the new values significantly formed by economic forces. This applies both internally, between professionals, and in the political-professional relationship.

Again, evaluation systems and the criteria on which they were founded were required to adapt to the new context. The most recent system, FOKUS (Competence Development and Evaluation System of the Danish Armed Forces), was 
launched in 2007 (Forsvarskommandoen, 2007; 2012). In the main, FORPUBS was abandoned on account of its outdated evaluation categories and the fact that the ambition of systematic competence development was not adequately supported (Lund, Jepsen \& Wedell-Wedellsborg, 2000). Thus, FOKUS became the first system with methodical user surveys playing a role in its design. It took as its starting point the relatively new concept of competence and the standards for state staff policy presented by the Ministry of Finance in the previous decade (Finansministeriet, 1998). The competences preferred by the users appeared to be cooperation, flexibility and adaptability related to the project value (Forsvarets Center for Lederskab, 2003). Through user surveys, the performance evaluation system thus accommodated a value that was formally new but which already existed in the officer corps.

The new system was not only intended to focus on individual competence development. The aim was to create an organisation capable of continually gaining insight and adaptation. Competence development was not considered a matter of changing one's personality; the entire organisational context and the relation between people became subject to evaluation. In the routine development dialogues, effective problem-solving was to be the focal point. This shift from personality to ever-changing problem-solving represented the new emphasis on adaptability and the formation of networks as a basis for varying activities, associated with the project value.

These societal drivers were reflected in the new competences in FOKUS. This is evident from the inclusion of the values of flexibility ("Adjusts to new demands"), holistic approach ("Understands the context of the task at hand"), future-orientation ("Demonstrates far-sighted leadership in connection with the development of the unit"), communication ("Listens actively and communicates clearly in writing and speech") and the development of others ("Supports the development of others"). These all relate to an activation of the project value's principles of activity, agility and flexibility. Corresponding to the Personnel Agency's view of leadership, they were at the top of the officers' own priority lists (Personalestyrelsen. 2003). The main value differences between FORPUBS and FOKUS were that the domestic value, ever-present in all previous systems and phases, now disappeared completely, while the project value, absent in previous systems, now became central in senior officership. FOKUS can be said, then, to represent the contemporary movement from domestic to industrial and project principles. As such, it also reflects the contextual development in both security and administration policy. (Forsvarskommandoen, 2008; Ejersbo \& Greve, 2014). In both cases, the ability to promote agility, responsiveness and efficiency can be considered the prominent value. Two qualitative terms in particular represented the emergence of the project value: modernisation, 
that is, breaking with tradition, and holistic understanding, that is, the will to make local changes with the collective in mind (Forsvarsministeriet 2012, p. 9).

Additionally, the new project competences were combined with industrial competences resembling the former FORPUBS competences: analytical mindset ("Carefully considers the parts of a task and options for solving it"), planning ("Predicts and plans each step of the problem solving process"), and resource conscious ("Prioritises goals and means on an ongoing basis, ensuring that resources are used in the best way possible"). In combination with the project competences, they form the ideal the officer as calculative change agent.

FOKUS also draws on other values that emerged in the previous phases. The execution value is represented by the competences decision making ("Makes necessary and effective decisions"), management ("Charts the course and coordinates efforts, ensuring that results are achieved in time") and initiative ("Independently launches appropriate activities"). Furthermore, the sacrificial value is represented by the competence handling pressure ("Keeps a sense of perspective and drive in stressful situations").

Indeed, while never appearing as dominant values, the execution value and the sacrificial value have been present through all phases, denoted by different qualitative concepts. Although the pure civic value from Phase 3 seems to be absent in FOKUS, elements of the industrial-civic ideal are still represented. It appears in the competencies motivates others ("Creates energy and will to act") and cooperation ("Contributes actively to solving the task in interaction with others").

\section{Discussion - Sedimentary Displacement of Values}

The historical analysis of performance evaluation systems discloses both the replacement and the displacement of values, showing how the systems themselves seem to adapt to and incorporate societal values as part of their requirements to officers. More, emerging values do not seem to entirely replace those preceding them; rather, in all the analysed cases, the dynamics seem to be a question of a type of displacement in which new constellations emerge with the "newest" value the most prominent, supplemented by previous values now forming secondary significances. In so doing, the systems and officers who apply them manage to create a new equilibrium between several incommensurable values inherent in the profession over time. They uphold traditional values and connect and adapt to new requirements and emerging values even though they seem, in principle, to be impossible to reconcile.

How are we to understand such value dynamics? As argued by Koselleck (2002), societal key values can be understood in both an epochal and sedimenta- 
$r y$ way. Whereas the epochal (Figure 1) illustrates which values dominate in a specific phase, the sedimentary illustrates a social value accumulation based on historical processes. Figure 2 illustrates the sedimentary tendency as it appears in the analysis. New values lie on top of already-existing values in the sense that they become predominant in the evaluations, thereby displacing the dominance of the prior value. The tendency to displace rather than replace values means that incommensurable values accrue in the military profession. This increases the complexity of a value system the actors are required to practically manage and to justify, both in internal evaluations and to the outside world.

Figure 2 illustrates how this happens parallel to societal changes through eras characterised by autocracy, industrialisation, democratisation and globalisation, as previously described in the unfolding of the four phases. Over time, the military profession seems to be capable of adapting professional values to societal change without giving up values inherited from previous phases. In this way, the profession simultaneously integrates and separates itself from the society, so allowing the emergence of a distinct professional self-understanding.

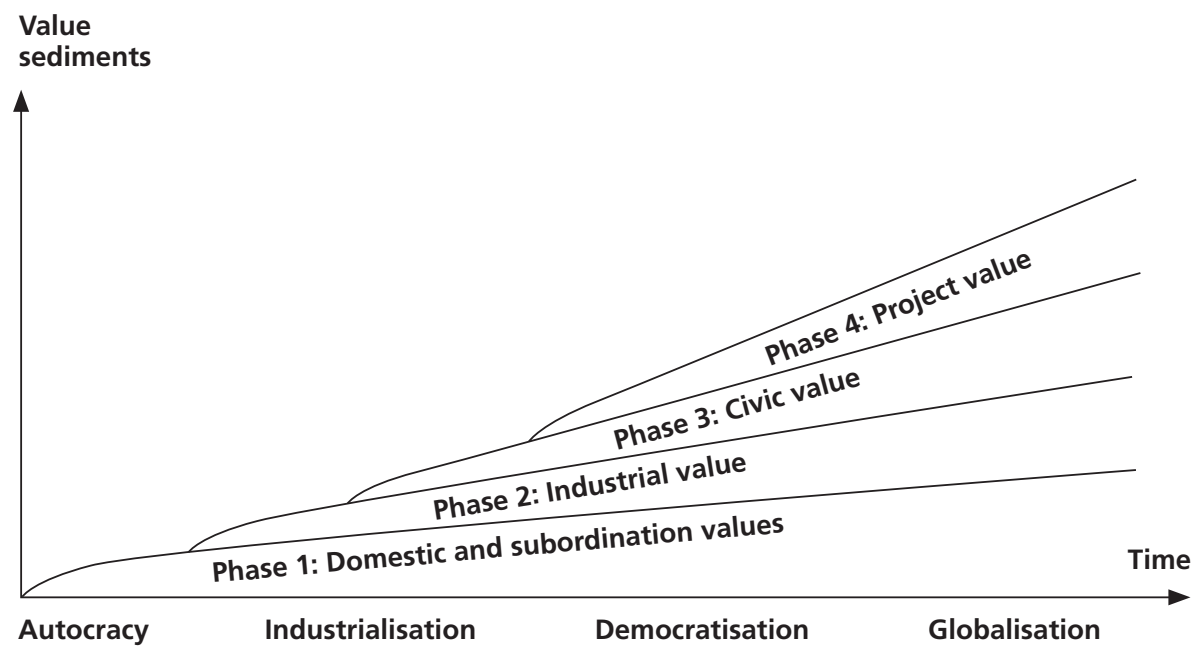

Figure 2. Sediment layers of Values in Military Officership.

It does not seem that the loss or the acquisition of core professional values is a reflection of changes in wider society but is, rather, generated autonomously. The following quotation from a Phase 3 evaluation exemplifies this in practice through a simultaneous appreciation of several values - domestic authority, industrial effectiveness and civic working relations - thereby drawing on sedimentary layers of values from Phases 1 to 3 : 
The lieutenant colonel is an extremely well-founded [industrial] officer with a pleasant nature, but at the same time an authoritative appearance [domestic]. He possesses a good portion of humour and a lot of humanity, and he has an appropriately well-controlled temperament. He understands ... how to build and maintain a good climate among his employees [civic]. (FOARK 8, Evaluation 1981)

Here, social qualities such as pleasantness, humour, humanity and self-control predominate, understood as capacities; the domestic authority is downgraded to the status of mere descriptor. As such, the quote reflects the tendency and priorities in Phase 3 evaluations.

The sedimented layers are also reflected in the formal evaluation categories as described above regarding FOKUS in Phase 4. Here, we experience a significant value displacement, with the tradition-based domestic value losing ground to the future-oriented project value. Indeed, the domestic value is entirely absent in the formal evaluation categories in FOKUS. While the argument could be made that it has been replaced by project qualities, the implementation of FOKUS offers only a partial explanation, since free text sections of the evaluations made by the officers themselves between 1989 and 2015 reveal that displacement had already begun. A survey of the entire stock of colonel and naval captain evaluations demonstrates that the evaluating officers themselves turn to project qualifiers, increasingly avoiding domestic qualifiers (Holsting, 2017, p. 181; Holsting \& Damkjer, 2020, p. 99); project qualifiers like flexibility, mobility, adaptability and coordination have gained ground; domestic qualifiers like authority and honour appear much less frequently (if, as the quotation from the evaluation attests, they do not disappear completely). This displacement continues, however, and the project value may very well become the predominant value of officership in the future - which would be remarkable, given that the domestic value has always formed a core part of officership, whereas the project value only has emerged in Phase 4.

Should this worry us? Or is it simply a logical and necessary consequence of the military profession's adaptation to a new context of increasing technological sophistication, diversity and change? Does the gradual displacement of the traditional domestic value express an increasing ability to look ahead and to integrate the leaders and actors of tomorrow? Or are we experiencing a dilution of the heroic officer trusted by society and willingly followed by soldiers? Certainly, these are important questions requiring further examination - but taking the sedimentary value perspective into consideration, the profession's response to societal change can be understood to be conservative, notwithstanding its inherent adaptability. 
It is difficult to determine exactly what has been the main driver of value displacement. As we have seen, both military conditions and general requirements for public management have challenged traditional hierarchical conceptions and motivated a more agile, holistic and future-oriented transformation. Anthony King (2019, p. 20), for instance, claims the existence of a historically distinctive commandship in the 21th century in which "commanders, partners, deputies and subordinates, have begun to manage complex, heterogeneous contemporary operations"; Stanley McChrystal (2015), similarly, stresses the transition from command to team effort in order to handle the increased speed and frequent disruptions of operations. Even Bernard Bass (2009, p. 288), a defender of a universal and traditional approach to the ideals of officership, acknowledges that "individualized considerations, as well as transformational leadership, would be important in establishing and maintaining the cohesiveness needed for [military] success." Remarkably, none of the authors reject the significance of traditional values, even while stressing the emerging ones. Management scientists, meanwhile, have identified several coexisting, even overlapping, management paradigms in contemporary public management in Denmark (Andersen, Greve, Klausen \& Torfig, 2020, p. 166). The sedimentary understanding of officership seems, therefore, to reflect most accurately the historical development while accounting for the increased complexity of values in today's officership.

The longue durée sedimentary approach used in this study offers an in-depth perspective which questions the usual myth of professional decline occurring every time core professional values are challenged. The empirical material demonstrates that the professional systems described are fully capable of managing and implementing new values without annulling those already existing. This pragmatic ability may be the very reason that a profession is capable of both adapting to future requirements and, as long as they are still needed in practice, maintaining existing qualities.

Returning to the initial discussion of whether military values are unique or general, universal or temporal, the analysis indicates that such distinctions are too simplistic in the sedimentary perspective. The officers' applications of evaluation systems indicate a continuous process of reprofessionalisation serving to integrate an increasing number of values. As stressed by Williams (2008), however, this increase in complexity and in what he perceives as cultural relativism also creates serious challenges to traditional military culture. In this there is a latent risk of simplistic responses to societal development, which may appear easier to understand. This is an issue deserving more attention. 


\section{Concluding Remarks}

The modern officer corps has emerged as a professional community founded on distinct constellations of professional values through a historical process originating, at the latest, in an autocratic society. These values are, however, closely tied to developments in society at large. Four general phases have been identified, each with distinct professional and societal implications and holding to very different types of the ideal officer. Professional military values seem to correspond with societal changes regarding domestic, industrial, civic and project values, while simultaneously insisting on values of execution, sacrifice and subordination at all times. The diachronic emergence of values demonstrates a continuous process of re-professionalisation characterised by a sedimentary accumulation of what, in principle, might appear to be incommensurable values. Through this process, the relation of the officer to the surrounding society is tightened while core professional qualities are maintained. Returning to the diverse understandings of military values as either unique or general, universal or temporal, an empirically informed response requires we acknowledge that, if military values are closely related to societal development, the way in which they are integrated is very distinct. 
Administrationsudvalget (1966). Administrationsudvalget af 1960: 5. Betenkning. Revisionsdepartementernes og hovedrevisionens forhold (Betænkning nr. 408). Retrieved from https://www.elov.dk/media/betaenkninger/Betaenkning_revisionsdepartementernes_og_hovedrevisionens_forhold.pdf

Andersen, L. B., Greve, C., Klausen, K. K., \& Torfig, J. (2020). Offentlige styringsparadigmer: Konkurrence og sameksistens [Public governance paradigms: Competition and coexistence] (2nd Ed.). Copenhagen, Denmark: Djøf Forlag.

Bass, B. N. (2009). Leading in the army after next. In R.L Taylor, W. E. Rosenbach \& E.B. Rosenbach (Eds.), Military leadership: In pursuit of excellence (pp. 285-301). Boulder, Colorado: Westview Press.

Berg, N. (1967). De grønne betænkninger - episode eller epoke [The green reports - episode or epoch]. Militert Tidsskrift, 113, 153-164.

Boëne, A. (1990). How "unique" should the military be? A review of representative literature \& outline of a synthetic formulation. European fournal of Sociology, 31(1), 3-59.

Burk, J. (1993). Morris Janowitz and the origins of sociological research on armed forces and society. Armed Forces \& Society, 19(2), 167-185. DOI: https://doi.org/10.1177/0095327X9301900202

Boltanski, L. (2012). Love and justice as competences: Three essays in the sociology of action (C. Porter, Trans.). Cambridge, UK: Polity Press (Original work published 1990).

Boltanski, L., \& Chiapello, E. (2005). The new spirit of capitalism. International fournal of Politics, Culture and Society, 18(3/4), 161-188. DOI: https://doi.org/10.1007/s10767-006-9006-9

Boltanski, L., \& Chiapello, E. (2007). The new spirit of capitalism (G. Elliot, Trans.). London, UK: Verso (Original work published 1999).

Boltanski, L., \& Thévenot, L. (2006). On Fustification: Economies of Worth (G. Porter, Trans.). Princeton, NJ: Princeton University Press (Original work published 1991).

Bousquet, A. (2009). The scientific way of warfare: Order and chaos on the battlefield of modernity. New York, NY: Columbia University Press.

Carlsson, T. (1948). Personalepolitiske foranstaltninger, især stillings- og personalebedømmelser, som led I den administrative rationalisering [Human resource initiatives, particularly job- and personnel assessments]. Ledelse og Erhverusøkonomi, 12, 84-113.

Chief of Defence (2020). Forsvarschefens prioriteter 2020 [Chief of Defence's priorities 2020]. Internal document.

von Clausewitz, C. (1981). Om krig [On war] (M. C. Jacobsen, trans.). Humlebæk, Denmark: Rhodos (Original work published 1832).

Ejersbo, N., \& Greve, C. (2014). Modernisering af den offentlige sektor (3rd ed.) [Modernisation of the public sector]. Copenhagen, Denmark: Akademisk Forlag Business.

Finansministeriet (1998). Personalepolitik $i$ staten - Fra ord til handling [personnel policy in the state - from word to action]. Copenhagen, Denmark: Finansministeriet.

Finkelstein, L. S. (1995). What is global governance? Global Governance, 1(3), 367-372. DOI: https://doi. org/10.1163/19426720-001-03-90000007

Forsvarets Center for Lederskab (2003). Scoringsark for fokusgrupper - Fordelt på vern, etc. (unpublished analysis of FOKUS development).

Forsvarskommandoen (1976). Padagogiske principper for Forsvaret (Annotated Ed.) [Pedagogical principles for the Danish Armed Forces]. Skovlunde, Denmark: S.L. Møllers Bogtrykkeri.

Forsvarskommandoen (1978). Forsvarets ledelsesprincipper (Annotated Ed.) [Leadership principles for the Danish Armed Forces]. Copenhagen, Denmark: Forsvarskommandoen.

Forsvarskommandoen (2000). Ved forenede krefter - forsvarets øverste militere ledelse: forsvarschefembedet og forsvarets udvikling 1950-2000 [By united forces - the top military leadership of the Armed Forces: the defence chief and the development of the Armed Forces 1950-2000]. Copenhagen, Denmakar: Forsvarskommandoen. 


\section{References}

Forsvarskommandoen (2007). Administrative bestemmelser vedr. Forsvarets kompetenceudviklings- og bedømmelsessystem (FOKUS) (FPTBST 405-5, 2008-2007) [Administrative provisions regarding The Armed Forces' competence development and assessment system (FOKUS)].

Forsvarskommandoen (2008). Forsvarets Ledelsesgrundlag (FKO FIR 121-5) [The Danish Armed Forces' management basis]. Retrieved from https://medarbejder.forsvaret.dk/globalassets/hr-portal/ dokumenter/2020/administration/-forsvarets_ledelsesgrundlag-.pdf

Forsvarskommandoen (2012). Administrative bestemmelser vedrorende forsvarets kompetenceudviklings- og bedømmelsessystem (FOKUS) (FKOBST 405-1.2012-3) [Administrative provisions regarding the Armed Forces' competence development and assessment system (FOKUS)]. Retrieved from http:// refoe.dk/userfiles/downloads/fokus/FOKUS-FKOBST405-1mar2012.pdf

Forsvarsministeriet (1966a). Betenkning nr. 428: Militer padagogik og ledelsesformer (Vol. 1) [Report No. 428: Military pedagogy and forms of leadership]. Copenhagen, Denmark: S.L. Møllers Bogtrykkeri.

Forsvarsministeriet (1966b). Betenkning nr. 429: Samarbejdsregler inden for Forsvaret (Vol. 2) [Report no. 429: Cooperation rules within the Armed Forces]. Copenhagen, Denmark: S.L. Møllers Bogtrykkeri.

Forsvarsministeriet (1969a). Betenkning nr. 516: Uddannelsen af forsvarets befalingsmand (Vol. 6) [Report No 516: The training of commanders in the Armed Forces]. Copenhagen, Denmark: S.L. Møllers Bogtrykkeri.

Forsvarsministeriet (1969b). Betenkning nr. 586: Straf og disciplinarmidler - Klageregler (Vol. 7) [Report no. 586: penalties and disciplinary measures - rules of appeal]. Copenhagen, Denmark: S.L. Møllers Bogtrykkeri.

Forsvarsministeriet (1976). Forsvarets personeludviklings- og bedømmelsessystem (FORPUBS) (B. 3-1976). In Kundgørelse for Forsvaret.

Forsvarsministeriet (2005). Forslag til militer straffelov (AG000236). Retrieved from https//www.retsinformation.dk

Forsvarsministeriet (2012). Redegørelse fra arbejdsgruppe om modernisering af ledelsen af Forsvaret [Statement from the working group on modernising the leadership of the Armed Forces]. Retrieved from https://www.ft.dk/samling/20111/almdel/fou/bilag/124/1136696.pdf

George, C. S. (1972). The history of management thought. Hoboken, NJ: Prentice-Hall.

Heise, V. P. (1953). Disciplin og disciplinære vanskeligheder i ny belysning [Discipline and disciplinary difficulties in a new light]. Tidsskrift for Sovesen, 124, 49-69.

Holsting, V. S. (2017). Militert chefoirke: Kritik og retferdiggørelse mellem politik og profession [Military commandship: criticism and justification between politics and profession]. (Doctoral dissertation, Copenhagen Business School, Denmark). Retrieved from https://research-api.cbs.dk/ws/ portalfiles/portal/58545681/Vilhelm_Holsting.pdf

Holsting, V. S., \& Damkjer, A. (2020). Militert chefvirke: At skabe handlekraft i komplekse situationer [Military leadership: creating action in complex situations]. Frederiksberg, Denmark: Samfundslitteratur.

Huntington, S. P. (1985). The soldier and the state: The theory and politics of civil-military relations. Cambridge, Mass.: The Belknap Press of Harvard University Press.

Hærkommandoen (1969). Ledelse og uddannelse: Militer padagogik [Leadership and education: military pedagogy]. Copenhagen, Denmark. S.L. Møllers Bogtrykkeri.

Janowitz, M. (1971). The professional soldier: A social and political portrait. New York, NY: The Macmillan Company.

Jensen, B. M., Olsen, O.P., Svensson, P. \& Zilmer, J. (2004). Fra kaft, trit og retning til moderne ledelse: Haren 195-1995 [From strict military discipline to modern leadership: The Army 195-1995]. Copenhagen, Denmark: Handelshøjskolens Forlag. 
King, A. (2019). Command: The twenty-first-century general. Cambridge, UK: Cambridge University Press

Koselleck, R. (2002). The practice of conceptual history: Timing, history, spacing concepts. Standford, California: Stanford University Press.

Krigsministeriet (1867). Kundgjorelser for heren for aaret 1867 [Procolamations for the army for the year 1867]. Copenhagen, Denmark: T.H. Schulz.

Krigsministeriet (1868a). Kundgjorelser for Haren for Aaret 1868 [Military announcements for the year 1868]. T.H. Schulz, Kjøbenhavn

Krigsministeriet (1868b). Udkast til reglement for tjenestegangen $i$ den Danske har [Draft regulations for the service in the Danish army]. Copenhagen, Denmark: T.H. Schulz.

Krigsministeriet (1870). Reglement indeholdende almindelige Bestemmelser for Tjenestegangen i Heren Regulations Containing General Provisions for the Service in the army]. Copenhagen, Denmark: T.H. Schulz.

Krigsministeriet (1880). Reglement indeholdende almindelige Bestemmelser for Tjenestegangen i Heren [Regulations containing general provisions for the service in the army]. Copenhagen, Denmark: T.H. Schulz.

Krigsministeriet (1881). Kundgjorelser for heren samt love og bestemmelser som angaa haren [Announcements for the army together with laws and regulations concerning the army]. Copenhagen, Denmark: Hansen.

Krigsministeriet (1908). Tjenestegangen i Heren [Army service]. Copenhagen, Denmark: Centraltrykkeriet. Krigsministeriet (1939). Tjenestereglement for Heren [Service regulations for the army].Copenhagen, Denmark: N. Olaf Møller, D. Quist \& Komp. Bogtrykkeri.

Leicht, K. T., Walter, T., Sainsaulieu, I., \& Davies, S. (2009). New public management and new professionalism across nations and contexts. Current Sociology, 57(4), 581-605. DOI: https://doi. org/10.1177\%2F0011392109104355

Libel, T. (2020). The rise and fall of the study of the military profession: From the sociology of the military profession to the sociology of security expertise. In K. K. Hachey, T. Libel \& W. H. Dean (Eds.), Rethinking Military Professionalism for the Changing Armed Forces (pp. 13-28). Cham., Switzerland: Springer.

McChrystal, S. (2015). Team of teams: New rules of engagement for a complex world. London, UK: Penguin Business.

Lund, J., Jepsen, M. M., \& Wedell-Wedellsborg, M. (2000). Evaluering og eventuel revision af Forsvarets personeludviklings- og bedommelsessystem (FORPUBS) [Evaluation and possible revision of the Armed Forces' personnel development and assessment system (FORPUBS)]. Copenhagen, Denmark: Forsvarets Center for Lederskab

Marineministeriet (1881). Samling af love og bestemmelser, som angaa savernet 1878-1880 [Collection of laws and regulations concerning the navy 1878-1880]. Copenhagen, Denmark: T.H. Schulz.

Marineministeriet (1950). Kundgørelser for søvarnet B. for året 1949 (B.1-B.17) [Announcements for the navy b. for the year 1949 (B.1-B.17)]. Copenhagen, Denmark: Centraltrykkeriet.

Moskos, C. (1977). From institution to occupation: Trends in military organization. Armed Forces \& Society, $4(1), 41-50$.

McLaughlin, K., \& Osborne, S. P. (2002). New public management. In K. McLaughlin, S. P. Osborne \& E. Ferlie (Eds.), New public management: Current trends and future prospects (pp. 34-53). New York, NY: Routledge.

Murphy, K. R., \& Cleveland, J. N. (1995). Understanding performance appraisal: Social, organization and goal-based perspectives. Thousand Oaks, California: SAGE Publications

Elias, N. (2007). The genesis of the naval profession. Dublin, Ireland: University College Dublin Press.

Olden-Jørgensen, S., Lyngby, T., \& Mentz, S. (2010). Magt og pragt-enevalde 1660-1848 [Power and splendour - autocracy 1660-1848]. Copenhagen, Denmark: Gad. 


\section{References}

Pedersen, R. B. (2012). Fra aktiv internationalisme til international aktivisme: Udvikling og tendenser i dansk udenrigspolitisk aktivisme [From active internationalism to international activism: development and trends in Danish foreign policy activism]. Politica, 44(1) 111-130.

Personalestyrelsen (2003). Statens personale- og ledelsespolitik 2003 - Gor en forskel [The state's personnel and management policy 2003 - make a difference]. Copenhagen, Denmark: Finansministeriet.

Petersen, E. (1967). Sanktioner og trivsel i et autoritert ledet system: en sociologisk-socialpsykologisk studie af samspillet mellem individet og det aktuelle miljo [Sanctions and well-being in an authoritarian-led system: a sociological-social-psychological study of the interaction between the individual and the current environment]. Copenhagen, Denmark: Nyt Nordisk Forlag.

Psykologikommissionen (1949). Betenkning fra kommissionen til behandling af militerpsykologiske sporgsmål [Report from the commission on treatment of military psychological issues]. Copenhagen, Denmark: Emil Kristensen.

von der Recke, C.F. (1861). Niels Juells conducteliste over marinens officeerspersonale anno 1690 [Niels Juell's Conducteliste over The Marines Officer personnel 1690]. Tidsskrift for Søvasen, 35, 168-193, 240-272

Rennison, B.W. (2011). Ledelsens genealogi [The genealogy of leadership]. Frederiksberg, Denmark: Samfundslitteratur

Sabroe, K-E., \& Rieneck, B. (1968). Lederskab og lederskabstrening [Leadership and Leadership training]. Copenhagen, Denmark: Militærpsykologisk Tjeneste.

Sarkesian, S. C. (1981). Beyond the battlefield: The new military professionalism. Oxford, UK: Pergamon Press.

Scott, W., Clothier, R. C., Spriegel, W. R. (1941). Personnel management: Principles, practices and point of viere. New York, NY: McGraw-Hill

Spates, J. L. (1983). The sociology of values. Annual Review of Sociology, 9, 27-49. DOI: https://doi. org/10.1146/annurev.so.09.080183.000331

Teitler, G. (1977). The genesis of the professional officer's corps. London, UK: Sage Publications.

Weise, D. S., \& Buckley, M. R. (1998). The evolution of the performance appraisal process. Fournal of Management History, 4(3), 233-249. DOI: https://doi.org/10.1108/13552529810231003

Williams, J. A. (2008). The military and society: Beyond the postmodern era. Orbis, 52(2), 199-216. DOI: https://doi.org/10.1016/j.orbis.2008.01.003

\section{Appendix: List of archives of historical performance evaluations}

The appendix shows an overview of archive entries examined in the Armed Forces Archives (FOARK) at the National Archives for charting historical officer assessment systems. Each archive unit is listed with both a unique serial number, which I use as a source reference, and the National Archives identification information, which can be used in a search in the National Archive's database, Daisy. Some archive series are classified and therefore require the approval of the National Archives and the Armed Forces. This applies to number 2, 3, 6, 7 and 8. 


\begin{tabular}{|c|c|}
\hline $\begin{array}{l}\text { Reference } \\
\text { numbers } \\
\text { in this article }\end{array}$ & $\begin{array}{l}\text { Military Archives (FOARK) } \\
\text { Specification of archival units representing } \\
\text { the empery of the study }\end{array}$ \\
\hline FOARK 1 & $\begin{array}{l}\text { Archive unit: Admiralitets- og Kommissariatskollegiet, Bogholder-, arkiv- } \\
\text { og depechekontoret } \\
\text { Archival series: Officersbedømmelser eller konduiteprotokoller (1756- } \\
\text { 1843) } \\
\text { - Record number: } 917 \text {, Content: konduiteprotokoller 1756-1788 }\end{array}$ \\
\hline FOARK 2 & $\begin{array}{l}\text { Archive unit: Krigsministeriet/ Forsvarsministeriet } \\
\text { Archival series: Officersforfremmelsesbedømmelser for officerer udtrådt } \\
\text { af aktiv tjeneste ca. 1900-1980 (Classified) } \\
\text { - Record number: } 1 \text { (Package 1, Officersforfremmelsesbedømmelser } \\
\text { 1880-1980), Content: From Aab to All }\end{array}$ \\
\hline FOARK 3 & $\begin{array}{l}\text { Archive unit: Forsvarsministeriet } \\
\text { Archival series: Personelbedømmelser for Flyvevåbnet, født 1932-1933 } \\
\text { (1932-1993) (Classified) } \\
\text { - Record number: 1, Content: From Aa to Ab }\end{array}$ \\
\hline FOARK 4 & $\begin{array}{l}\text { Archive unit: Marineministeriet, Sekretariats- og Kommandokontoret } \\
\text { Archival series: Forfremmelsesbedømmelser for søofficerer (1815-1927) } \\
\text { - Record number: 1a, Content: From } 1860 \text { to } 1920\end{array}$ \\
\hline FOARK 5 & $\begin{array}{l}\text { Archive unit: Marineministeriet, Sekretariats- og Kommandokontoret } \\
\text { Archival series: Forfremmelsesbedømmelser for søofficerer (1815-1927) } \\
\text { - Record number: 9, Content: From } 1906 \text { to } 1927\end{array}$ \\
\hline FOARK 6 & $\begin{array}{l}\text { Archive unit: Marineministeriet, Sekretariats- og Kommandokontoret } \\
\text { (Forsvarsministeriet) } \\
\text { Archival series: (kontraadmiraler, kommandører, mm) } \\
\text { Record number: } 228 \text { (Package 228) (Classified) } \\
\text { - Package 228: Kontraadmiraler, kommandører, m.m. , Content: } \\
\quad \text { From } 1939 \text { to } 1967\end{array}$ \\
\hline FOARK 7 & $\begin{array}{l}\text { Archive unit: Marineministeriet, Sekretariats- og Kommandokontoret } \\
\text { (Forsvarsministeriet) } \\
\text { Archival series: (kontraadmiraler, kommandører, mm) } \\
\text { Record number: } 231 \text { (Package 231) (Classified) } \\
\text { - Package 231: Kommandørkaptajner, Content: From } 1924 \text { to } 1969\end{array}$ \\
\hline FOARK 8 & $\begin{array}{l}\text { Archive unit: Forsvarets Arkiver (FOARK), Militære personelfortegnelser } \\
\text { Archival series: Forfremmelsesbedømmelser - Hæren (officerer) 1980- } \\
2000 \text { (Classified) } \\
\text { - Record number: 1, Content: From Aa to Am }\end{array}$ \\
\hline FOARK 9 & $\begin{array}{l}\text { Archive unit: Marineministeriet, Sekretariats- og Kommandokontoret } \\
\text { Archival series: Søofficersbedømmelser } \\
\text { - Record number 2, Content 1036-1261 (From } 1809 \text { to 1938) }\end{array}$ \\
\hline
\end{tabular}




\section{Appendix}

\begin{tabular}{|c|c|}
\hline $\begin{array}{l}\text { Reference } \\
\text { numbers } \\
\text { in this article }\end{array}$ & $\begin{array}{l}\text { Military Archives (FOARK) } \\
\text { Specification of archival units representing } \\
\text { the empery of the study - continued }\end{array}$ \\
\hline FOARK 10 & $\begin{array}{l}\text { Archive unit: Krigskollegiet, Krigskancelliet } \\
\text { Archival series: Konduitelister } \\
\text { - Record number: } 1818 \text {, Content 1730-1733 (From } 1730 \text { to 1899) }\end{array}$ \\
\hline FOARK 11 & $\begin{array}{l}\text { Archive unit: Krigsministeriet } \\
\text { Archival series: Forfremmelseslister } \\
\text { - Record number: } 18 \text {, Content: } 1868 \text { Officerer ved Generalstaben m.m. } \\
\text { (From } 1869 \text { to 1909) }\end{array}$ \\
\hline FOARK 12 & $\begin{array}{l}\text { Archive unit: Krigsministeriet, } \\
\text { Archival series: Konduite- og avancementslister (1764-1849) } \\
\text { - Record number: 16, Content: 1853, 1856, 1857, } 1860 \text { and } 1866 \\
\text { Archive unit: Krigsministeriet } \\
\text { Archival series: Konduite- og avancementslister (1764-1849) } \\
\text { - Record number: 14, Content: Konduitelister 1847 Samtlige afdelinger } \\
\text { og korps med flere }\end{array}$ \\
\hline FOARK 14 & $\begin{array}{l}\text { Archive unit: Krigsministeriet } \\
\text { Archival series: Konduite- og avancementslister (1764-1849) } \\
\text { - Record number: 1, Content: } 1764\end{array}$ \\
\hline FOARK 15 & $\begin{array}{l}\text { Archive unit: Marineministeriet, Sekretariats- og Kommandokontoret } \\
\text { Archival series: Søofficersbedømmelser (1809-1938) } \\
\text { - Record number: 1, Content: Søofficersbedømmelser from } 1807 \\
\text { to } 1869\end{array}$ \\
\hline FOARK 16 & $\begin{array}{l}\text { Archive unit: Marineministeriet, Sekretariats- og Kommandokontoret } \\
\text { Archival series: Konduite- og forfremmelseslister for skibschefer (from } \\
1848 \text { to 1885) } \\
\text { - Record number: 1, Content: From } 1848 \text { to } 1871\end{array}$ \\
\hline FOARK 17 & $\begin{array}{l}\text { Archive unit: Krigsministeriet } \\
\text { Archival series: Konduite- og avancementslister (From } 1764 \text { to 1849) } \\
\text { - Record number: } 17 \text {, Content: Konduitelister } 1867\end{array}$ \\
\hline FOARK 18 & $\begin{array}{l}\text { Archive unit: Marineministeriet, Sekretariats- og Kommandokontoret } \\
\text { Archival series: Forfremmelsesbedømmelser for søofficerer } \\
\text { - Record number: 8, Content: 1848-1851, 1864, 1871, 1875, } 1882 \\
\text { and 1886-1905 }\end{array}$ \\
\hline FOARK 19 & $\begin{array}{l}\text { Archive unit: Søkrigskancelliet (Søetaten), Admiralitets- og Kommissari- } \\
\text { atskollegiet, Bogholder-, arkiv- og depechekontoret } \\
\text { Archival series: Konduitelister (1755-1843) } \\
\text { - Record number: } 916 \text {, Content: From } 1830 \text { to } 1843\end{array}$ \\
\hline
\end{tabular}




\begin{tabular}{|c|l|}
\hline $\begin{array}{l}\text { Reference } \\
\text { numbers } \\
\text { in this article }\end{array}$ & $\begin{array}{l}\text { Military Archives (FOARK) } \\
\text { Specification of archival units representing } \\
\text { the empery of the study - continued }\end{array}$ \\
\hline FOARK 20 & $\begin{array}{l}\text { Archive unit: Søkrigskancelliet (Søetaten), Admiralitets- og Kommissari- } \\
\text { atskollegiet, Bogholder, arkiv- og depechekontoret } \\
\text { Archival series: Konduitelister (1755-1843) } \\
\text { - Record number 915, Content: From 1810 to 1829 }\end{array}$ \\
\hline FOARK 21 & $\begin{array}{l}\text { Archive unit: Søkrigskancelliet (Søetaten), Admiralitets- og Kommissari- } \\
\text { atskollegiet, Bogholder, arkiv og depechekontoret } \\
\text { Archival series: Officersbedømmelser eller konduiteprotokoller (from } \\
\text { 1756 to 1843) } \\
\text { - Record number: 919b, Content: Mandskabsbedømmelser from 1833 } \\
\text { to 1843 }\end{array}$ \\
\hline FOARK 22 & $\begin{array}{l}\text { Archive unit: Søkrigskancelliet (Søetaten), Admiralitets- og Kommissari- } \\
\text { atskollegiet, Bogholder, arkiv- og depechekontoret } \\
\text { Archival series: Konduitelister (From 1755 to 1843) } \\
\text { - Record number: 914, Content: From 1800 to 1809 }\end{array}$ \\
\hline FOARK 23 & $\begin{array}{l}\text { Archive unit: Krigsministeriet } \\
\text { Archival series: Konduite- og avancementslister (1764-1849) } \\
\text { - Record number: 6, Content: Konduitelister for annekterede } \\
\text { batailloners officerer From 1808 to 1809 and 1814 m.m. }\end{array}$ \\
\hline
\end{tabular}

